\title{
Earnings Management Through Real Activities: The Role Of Audit Quality And Ownership Structure
}

\author{
Istianingsih $^{\mathrm{a}}$, IcukRanggaBawono ${ }^{\mathrm{b}}$ \\ ${ }^{a}$ UniversitasBhayangkara Jakarta Raya, Indonesia \\ ${ }^{\mathrm{b}}$ UniversitasJenderalSoedirman, Indonesia
}

Article History: Received: 10 November 2020; Revised 12 January 2021 Accepted: 27 January 2021; Published online: 5 April 2021

\begin{abstract}
This study aims to examine the effect of audit quality and ownership structure on earnings management through real activities. The audit quality tested is the size of the public auditor's office and auditor independence. The ownership structure that has been examined for its impact on management management is institutional ownership, managerial ownership, and foreign ownership. Earnings management through real activities is measured by three methods, namely abnormal cash flow from operation (CFO), abnormal discretionary expense, and abnormal production cost. The sample of this research is manufacturing companies listed on the Indonesia Stock Exchange from 2016 to 2018. With the purposive sampling method, the final sample is 175 company-years. The results showed that auditor quality and ownership structure had no effect on earnings management as measured by abnormal CFO. Meanwhile, abnormal production cost is not proven to be influenced by ownership structure but is negatively affected by audit quality as measured by Auditor Firm size. Ownership structure and audit quality are proven to have an effect on earnings management, which is measured by abnormal discretionary expense.

Keywords: audit quality, real earnings management, ownership structure,
\end{abstract}

\section{Background}

One of the numbers that is the most focused attention in financial statements is accounting profit because it is considered as one of the main indicators of a company's financial performance. This profit is a source of information in making investment and credit decisions. This is in line with Statement of Financial Accounting Concept (SFAC) No.1, which states that earnings information is generally the main concern of financial reports in determining management performance. In addition, earnings information also helps owners or other parties in estimating the company's future earnings power.

This similarly important earnings information is often followed. become engineering targets through opportunistic management actions. These opportunistic actions are carried out by selecting certain accounting policies so that earnings can be regulated. Earnings management is a management action in the process of preparing financial reporting so that it can increase or decrease accounting profit according to its interests (Scott, 2015). Earnings management arises because of agency problems related to the separation of ownership and management.

Agency Problem is caused by information asymmetry between managers and shareholders. This information asymmetry provides flexibility for management to determine the method of accounting for reporting company earnings (Lev, 1989). Management action decisions are largely unobserved and the goals between managers and shareholders are misaligned. These opportunistic actions are taken to maximize their utility at the expense of other stakeholders. Eldenburg et al., (2011). The generally accepted flexibility in the process of implementing accounting principles causes management to choose accounting policies that fulfill their opportunistic requirements.

Several cases that occurred in Indonesia, such as PT. Lippo Tbk and PT. Kimia FarmaTbk involves financial reporting that begins with the detection of manipulation (Boediono, 2005) and most recently the PT Garuda Indonesia case. Starting from the financial statements of Garuda Indonesia for the 2018 financial year which recorded a net profit of USD809.85. Meanwhile in 2017 PT.Garuda stated a loss of USD216.5 million. The 2018 financial statements are not in accordance with the Statement of Financial Accounting Standards (PSAK) because Garuda Indonesia includes PT Mahata Aero Teknologi's debt as profit.

Another case that is also rife is the SunPrima Nusantara Financing or SNP Finance in 2018. The case that occurred was the theft of 14 bank loans with a loss of up to Rp 14 trillion or US \$ 1 billion. Referring to the statement of the Indonesian Ministry of Finance, it was stated that public accountants who audited SNP Finance's financial statements violated professional auditing standards. Based on official data from the Financial Professional Development Center (PPPK), the auditors have not fully implemented information system controls related to customer data and the accuracy of the financial 
accounts receivable journal for the 2012-2016 financial year. In addition, the auditors have also not implemented sufficient and appropriate audit evidence to obtain accounts receivable. consumer finance. They have not implemented adequate procedures related to the fraud risk detection process.

Another case that also happened and greatly shocked the Indonesian accounting world was PT AsuransiJiwasraya (Persero) which experienced a default in October 2018 with an estimated deposit value of US \$ 1.2 billion or Rp.16.8 trillion. Utami (2006) conducted a comparative study on earnings management in several countries, and Indonesia was the country with the highest level of earnings management. Various cases and the existence of empirical evidence that the level of earnings management of issuers in Indonesia is relatively high and the level of protection against investors is low, raises the question of whether investors are aware of this earnings management. Does investors also consider the amount of accruals (proxies for earnings management) in determining the required level of return on shares on their investment.

One of the investors that should encourage improvement in management performance is the institutional owner. Ownership by institutional investors such as insurance companies, banks, investment companies and ownership by other institutions that are sophisticated investors should not be easily fooled by the actions of managers. Apart from institutions, managers who own options shares in the company should also be able to maintain the alignment of the company's goals with those of investors.

The higher the proportion of managerial share ownership, the better the company's performance should be, because management is more motivated to improve company performance. It is expected that with this institutional and managerial ownership, the level of earnings management will decrease. This negative relationship between managerial and institutional ownership has been proven in the research results of Darmawati (2005) and Saeed and Saeed (2018).

Apart from these two types of ownership, in Indonesia there is also foreign capital ownership in public companies. Bopkin and Isshaq (2009) state that foreign ownership tends to be selective in investment. They demand greater disclosure in financial reports. Ramaswary and Li (2001) found that the participation of foreign investors in the stock market has added to several regulatory changes. Investors demand better protection and a better company management structure so as to increase company value.

Various cases of fraud involving auditors demand better audit quality in detecting earnings management activities. Nurina (2011) argues that qualified auditors are able to detect earnings management by clients, so managers will tend to limit the amount of discretionary accruals. According to research conducted by Mahdi et al. (2005) there are several audit quality indicators that can be used to detect earnings management, such as the size of public accounting firms and auditor independence.

Various previous studies have found that managers are involved in earnings management activities. Broadly speaking, there are two patterns of earnings management, namely 1) through the choice of accrual-based accounting method; and 2) through real transactions. Various previous studies have focused more on accrual earnings management (for example, Healy and Wahlen, 1999). Meanwhile, other studies have found evidence that earnings management is carried out using real transaction activities (Roychowdhury, 2006; Cohen and Zarowin, 2010). Graham et al. (2005) found evidence that managers are more likely to perform earnings management through real activities than accrual-based earnings management. The documentation of the development of more recent patterns of earnings management above, implies a very crucial role of auditors and ownership structure in reducing or inhibiting possible forms of earnings management for public companies.

This study focuses on the effect of audit quality and ownership structure in minimizing earnings management practices through real activities. As far as the existing literature examines, previous studies examining the relationship of audit quality to real transaction earnings management activities are still limited (for example, Chi et al., 2011). Earnings management through real transactions can reduce the earnings quality of public companies, however Chi et al. (2011) found otherwise. The results of research in Indonesia conducted by Ratmono (2010) cannot prove that there is a relationship between real transactions and earnings quality. This study attempts to fill the research gap by examining directly the effect of audit quality on forms of earnings management in real transactions that occur in Indonesia.

The difference between this study and previous research lies in (1) the object of research, namely manufacturing companies listed on the Indonesia Stock Exchange. Manufacturing companies are selected to prevent bias in the calculation of Real Activity in detecting earnings management; (2) the addition of independent variables, namely share ownership structure which includes institutional ownership, management ownership and foreign ownership. This research is expected to provide references and knowledge regarding the influence of ownership structure and auditor quality on earnings management in developing countries, especially Indonesia. 


\section{Literature Review And Hypothesis Development}

\section{2.a. Agency Theory}

Agency theory explains the relationship or contract between the principal and agent. The principal is the shareholder or owner of the company while the agent or management is the party the owner pays to manage the company. Agency theory is embodied in a work contract that regulates the proportion of rights and obligations of each taking into account the overall benefit. Thus agency theory is the right contract design to align the interests of principals and agents in the event of different interests (Scott, 2015).

There are two potential agency conflicts, namely agency problems between management and shareholders (Jesen and Meckling, 1976) and second, agency problems between majority and minority shareholders (Shleifer and Vichny, 1996). In Indonesia, the first agency problem rarely occurs because, as stated by La Porta et al. (1999) that public companies in Indonesia have a concentration of ownership or are controlled by large shareholders.

Agency theory explains the causes of earnings management. An imbalance in the control of information between management and owners will provide opportunities for managers to carry out earning management so that it will mislead owners regarding their performance. Often the information managers provide to owners does not reflect the true financial condition of the company. The basis of agency theory in this study is the difference in interests between agents and principals to maximize their respective welfare.

The role of the auditor in agency theory is to test that the financial statement figures used in the contract have been calculated using applicable procedures (Watts and Zimmerman, 1986). Financial report audit by auditor acts as monitoring to test the credibility of accounting information produced by management. Opportunistic earnings management is a form of agency cost. Managers try to hide company performance from parties outside the entity in order to control (Caskey et al., 2016).

\section{2.b. Earnings management}

Earnings management is the choice of accounting policies by managers. Scott, (2015) states that there are two perspectives on earnings management, namely 1) it is management's opportunistic behavior to maximize its utility related to compensation contracts, debt contracts and political costs and, 2) efficient contracts, where earnings management gives managers the flexibility to protect themselves. them and the company in anticipation of uncertainty. Meanwhile, Healy and Wehlen (1998) state that earnings management occurs when managers change transactions to manipulate financial reports so as to mislead stakeholders. This research takes the side that earnings management is the opportunistic behavior of managers to maximize their utility. Earnings management is done by selecting certain accounting methods or policies to increase profits or decrease company profits.

This study uses a measure of earnings management which is carried out through real activities. Some researchers refer to real transaction earnings management as "real activity manipulation" (eg, Roychowdhury, 2006; Cohen and Zarowin, 2010). Profit manipulation through real activity is carried out to avoid reporting annual losses. Manipulation of real activities is carried out through: 1) giving discounts to increase temporary sales that have an impact on reducing operating cash flow (abnormal CFO), 2) overproduction to report costs that are lower than the cost of goods sold (abnormal production costs), and 3) delaying various operational expenses, including research and development costs, are included in the abnormal discretionary expenditure group (Roychowdhury, 2006; and Cohen and Zarowin (2010).

\section{Hypothesis Development}

\section{Audit Quality And Income Management}

Qualified auditors are considered capable of maintaining their credibility so that they are more careful in carrying out the audit process to detect misstatements or fraud. Qualified auditors will perform quality audits as well (Bartov et al., 2000). This study uses two indicators to describe the quality of auditors, namely Auditor Firm Size and auditor independence.

\section{Auditor Firm Size with real transaction earnings management}

Real transaction earnings management is a deviation from the company's normal operating practices (Roychowdhury, 2006). Auditors have a role as capital market gatekeepers in maintaining the quality of financial reporting by reducing opportunities for earnings management (Ronen and Yaari, 2008). The purpose of the financial statement audit is to provide assurance regarding the integrity of financial reporting. Qualified auditors are seen as inhibiting the opportunist behavior of managers. 
Audit quality is often measured by the size of the Auditor Firm Size (Herusetya, 2014). Auditors who work at Big Four Auditor Firm Size are considered more qualified because they are equipped with a series of training and procedures and have an audit program that is considered more accurate and effective than auditors from non-Big Four Auditor Firm Size. Big four Auditor Firm Size is believed to be of higher quality in auditing financial statements, and works as well as possible according to applicable procedures to maintain its reputation so that managers will not dare to practice earnings management. Welvin et al (2011) found that Auditor Firm Size has a negative effect on earnings management. Auditor Firm Size big four has a better ability in detecting earnings management activities than using Auditor Firm Size non big four. The larger the Auditor Firm Size, the better it will be able to detect and limit earnings management practices than the smaller Auditor Firm Size.

\section{H1: Firm size has a negative effect on earnings management through real activities.}

\section{Auditor independence with earnings management}

Auditor independence is defined as not easily influenced, because he carries out his work for the public interest. An independent auditor is one of the factors that can reduce earnings management. Public accountants are relatively more independent than internal auditors in minimizing cases of earnings engineering. As an independent party, the auditor has the ability to detect earnings management depending on the quality of the auditor. Research by Sylvia et. al, (2012) proves that auditor independence has a negative effect on earnings management. The higher the auditor independence, the better the resulting audit quality and the lower the occurrence of earnings management practices.

\section{H2: Auditor independence has a negative effect on earnings management}

\section{Institutional Ownership with Earnings Management}

Institutional ownership is ownership of company shares owned by financial institutions such as insurance companies, banks, pension funds and investment banking (Siregar and Utama, 2005). Research Classens et al. (2000) proved that the value of a company will be higher in companies owned by financial institutions sponsored by banks. Therefore Classens et al. (2000) stated that ownership by a bank will reduce the possibility of the company going bankrupt. If the company is owned by a bank, it will be easier to get an injection of funds from the bank when facing financial problems. The results of the study by Classens et al (2000) are supported by the research of Yohana (2010) which found that institutional ownership has a negative and significant relationship to earnings management.

The monitoring capabilities possessed by banks and financial institutions will be able to reduce managers' incentives in manipulating profits. The higher the institutional ownership, the lower the profit management practices. Based on this description, the formulation of the next hypothesis is:

\section{H3: Institutional ownership has a negative effect on earnings management}

\section{Managerial Ownership with earnings management}

Managerial ownership is shares that are owned individually or by subsidiaries of the company concerned and its affiliates (Susiana and Herawati, 2007). Managers who own shares in the company where they work will also feel like they own the company. This sense of belonging will have an impact on a careful attitude in reporting company finances. The higher the managerial ownership, the lower the earnings management activity because the manager has an interest in company shares. Alves' research (2012) also states that managerial ownership has a negative effect on earnings management. Managerial share ownership encourages managers to increase firm value because managers bear the proportion of wealth as shareholders. By owning company shares, the desire to deceive investors is reduced because managers share the good and bad consequences of the decisions taken. The higher the managerial ownership, the lower the earnings management practice.

\section{H4: Managerial ownership has a negative relationship with earnings management}

\section{Foreign Ownership with earnings management}

Salvatore (2005) states that a portfolio containing foreigners has a lower level of risk than a portfolio containing only domestic stocks. The rate of return from foreign ownership will be higher than domestic ownership only. This can be a consideration for shareholders. Foreign owners in Indonesia tend to demand greater openness in disclosure. With the presence of foreign owners, monitoring of opportunities for manipulation will be better. The higher the foreign share ownership, the less earnings management behavior will occur.

\section{H5: Foreign ownership has a negative effect on earnings management}

The occurrence of many cases of manipulation of earnings which is often carried out by management makes the company obliged to have a supervisory mechanism to minimize earnings management practices. This study 
takes audit quality and ownership structure as a supervisory mechanism that can minimize earnings management. The model in this study can be described in the following framework:

Figure 2.1. Theoretical Framework

\section{Audit Quality}

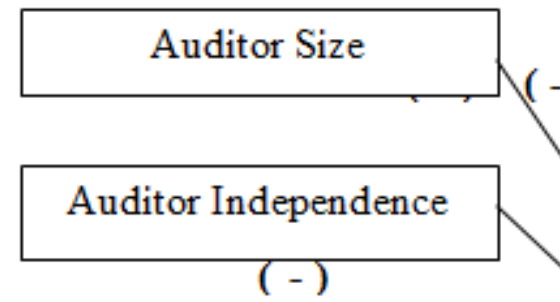

\section{Ownership Structure}

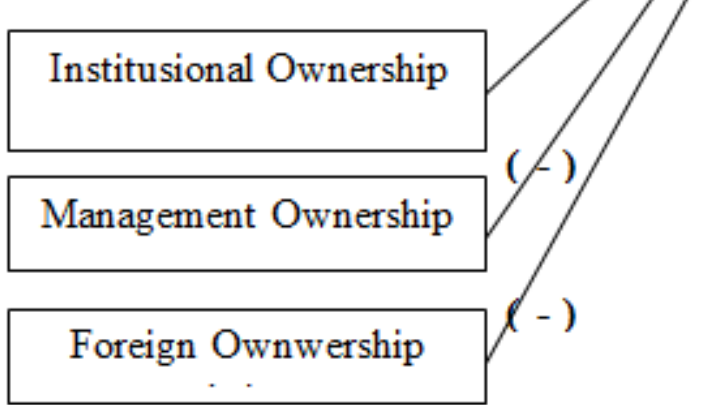

\section{Research Method}

\section{3.a. Population and Sample}

The population of this research is all manufacturing companies listed on the Indonesia Stock Exchange (BEI) in 2016-2018. . The sample does not include banking companies, credit agencies, securities, insurance, construction, real eastate and property, investment and telecommunications companies, because the presentation of their financial statements is different from those of financial reports in general.

The sample was determined by using purposive sampling method based on the criteria 1) Manufacturing companies listed on the IDX in 2016-2018 that published audited financial reports; and 2) have complete data on ownership of Agency, management and foreign shares and other data to be researched. The research data is secondary data obtained from the IDX website, namely www.idx.co.id, and the company website.

\section{3.b. Definition and Operations of Variables}

\section{Earnings management through real activities}

Earnings management in this study uses real activity which is divided into three measurement methods, namely abnormal cash flow from operation (ACFO), abnormal cost of good sold (ACOGS), abnormal discretionary expenses (ADISEXP), abnormal inventory and production cost (APROD).

Abonormal cash flow is the difference from the actual cash flow from operating activities with normal cash flow which is calculated using the estimated regression coefficient from each industry. The step to calculate abnormal cash flow begins with calculating normal cash flow as follows:

$$
\mathrm{CFO}_{\mathrm{it}} / \mathrm{A}_{\mathrm{i}, \mathrm{t}-1}=\alpha_{0}+\alpha_{1}\left(1 / \mathrm{A}_{\mathrm{i}, \mathrm{it}-1}\right)+\alpha_{2}\left(\mathrm{~S}_{\mathrm{it}} / \mathrm{A}_{\mathrm{i}, \mathrm{t}-1}\right)+\alpha_{3}\left(\Delta \mathrm{S}_{\mathrm{it}} / \mathrm{A}_{\mathrm{i}, \mathrm{t}-1}\right)+\varepsilon_{\mathrm{it}}
$$

$$
\Delta \mathrm{S}_{\mathrm{it}}=\mathrm{S}_{\mathrm{it}}-\mathrm{S}_{\mathrm{i}, \mathrm{t}-1}
$$


The regression coefficients of the actual cash flows above are entered into the equation below, the goal is to get normal cash flow.

$$
\mathrm{NCFO}_{\mathrm{it}}=\alpha_{0}+\alpha_{1}\left(1 / \mathrm{A}_{\mathrm{i}, \mathrm{it}-1}\right)+\alpha_{2}\left(\mathrm{~S}_{\mathrm{it}} / \mathrm{A}_{\mathrm{i}, \mathrm{t}-1}\right)+\alpha_{3}\left(\Delta \mathrm{S}_{\mathrm{it}} / \mathrm{A}_{\mathrm{i}, \mathrm{t}-1}\right)+\varepsilon_{\mathrm{it}}
$$

Furthermore, abnormal cash flow (ACFO) can be calculated as follows:

$$
\mathrm{ACFO}_{\mathrm{it}}=\mathrm{CFO}_{\mathrm{it}} / \mathrm{A}_{\mathrm{it}-1}-\mathrm{NCFO}_{\mathrm{it}}
$$

Information:

ACFOit $=$ abnormal cash flow of company $\mathrm{i}$ in period $\mathrm{t}$

NCFOit $=$ normal cash flow of company $\mathrm{i}$ in period $\mathrm{t}$

CFOit $=$ cash flow from company $\mathrm{i}$ operations in period $\mathrm{t}$

Ai, $\mathrm{t}-1=$ total assets of company $\mathrm{i}$ in period $\mathrm{t}$

$\mathrm{Sit}=$ sales of company $\mathrm{i}$ in period $\mathrm{t}$

$\Delta \mathrm{Sit}=$ the difference in sales of company $\mathrm{i}$ in period $\mathrm{t}$

Abonormal discretionary expenseis the difference between actual discretionary expense and normal discretionary expense which is calculated using the estimated regression coefficient for each industry. Discretionary expenses include R\&D expenses, advertising expenses, selling expenses and general and administrative expenses. If the R\&D load and advertising expense are not present, it can be calculated as zero. The regression equation is as follows:

$$
\operatorname{DISEXP}_{\mathrm{it}} / \mathrm{A}_{\mathrm{i}, \mathrm{t}-1}=\alpha_{0}+\alpha_{1}\left(1 / \mathrm{A}_{\mathrm{i}, \mathrm{it}-1}\right)+\alpha_{2}\left(\mathrm{~S}_{\mathrm{it}} / \mathrm{A}_{\mathrm{i}, \mathrm{t}-1}\right)+\alpha_{3}\left(\Delta \mathrm{S}_{\mathrm{it}} / \mathrm{A}_{\mathrm{i}, \mathrm{t}-1}\right)+\varepsilon_{\mathrm{it}}
$$

The regression coefficient of actual discretionary expense above is entered into the equation below, to get the normal value of discretionary expense:

$$
\operatorname{NDISEXP}_{\mathrm{it}}=\alpha_{0}+\alpha_{1}\left(1 / \mathrm{A}_{\mathrm{i}, \mathrm{it}-1}\right)+\alpha_{2}\left(\mathrm{~S}_{\mathrm{it}} / \mathrm{A}_{\mathrm{i}, \mathrm{t}-1}\right)+\alpha_{3}\left(\Delta \mathrm{S}_{\mathrm{it}} / \mathrm{A}_{\mathrm{i}, \mathrm{t}-1}\right)+\varepsilon_{\mathrm{it}}
$$

Furthermore, abnormal discretionary expense (ADISEXP) can be calculated as follows:

$$
\mathrm{ADISEXP}_{\text {it }}=\text { DISEXP }_{\text {it }} / \mathrm{A}_{\text {it }-1}-\mathrm{NDISEXP}_{\text {it }}
$$

Where:

ADISEXPit $=$ abnormal discretionary expense for company $\mathrm{i}$ in period $\mathrm{t}$

NDISEXPit $=$ normal discretionary expense for company $\mathrm{i}$ in period $\mathrm{t}$

DISEXPit $=$ discretionary expenses company $\mathrm{i}$ in period $\mathrm{t}$

$\mathrm{Ai}, \mathrm{t}-1=$ total assets of company $\mathrm{i}$ in period $\mathrm{t}$

Sit $=$ sales of company $\mathrm{i}$ in period $\mathrm{t}$ 
Abonormal production costis the difference between the actual production cost and the normal production cost, which is calculated using the estimated regression coefficient from each industry. The regression equation is as follows:

$$
\mathrm{PROD}_{\mathrm{it}} / \mathrm{A}_{\mathrm{i}, \mathrm{t}-1}=\alpha_{0}+\alpha_{1}\left(1 / \mathrm{A}_{\mathrm{i}, \mathrm{it}-1}\right)+\alpha_{2}\left(\mathrm{~S}_{\mathrm{it}} / \mathrm{A}_{\mathrm{i}, \mathrm{t}-1}\right)+\alpha_{3}\left(\Delta \mathrm{S}_{\mathrm{it}} / \mathrm{A}_{\mathrm{i}, \mathrm{t}-1}\right)+\varepsilon_{\mathrm{it}}
$$

$$
\mathrm{PROD}_{\text {it }}=\mathrm{COGS}_{\mathrm{it}}+\Delta \mathrm{INV}_{\mathrm{it}}
$$

The regression coefficient of the actual production cost above is entered into the equation below, to get the normal value of production cost:

$$
\mathrm{NPROD}_{\mathrm{it}}=\alpha_{0}+\alpha_{1}\left(1 / \mathrm{A}_{\mathrm{i}, \mathrm{it}-\mathrm{l}}\right)+\alpha_{2}\left(\mathrm{~S}_{\mathrm{it}} / \mathrm{A}_{\mathrm{i}, \mathrm{t}-1}\right)+\alpha_{3}\left(\Delta \mathrm{S}_{\mathrm{it}} / \mathrm{A}_{\mathrm{i}, \mathrm{t}-1}\right)+\varepsilon_{\mathrm{it}}
$$

Then the abnormal cost of good sold can be calculated as follows:

$$
\mathrm{APROD}_{\mathrm{it}}=\mathrm{PROD}_{\mathrm{it}} / \mathrm{A}_{\mathrm{it}-1}-\mathrm{NPROD}_{\mathrm{it}}
$$

Where:

APRODit $=$ abnormal production cost of company $\mathrm{i}$ in period $\mathrm{t}$

NPRODit $=$ normal production cost of company $\mathrm{i}$ in period $\mathrm{t}$

PRODit $=$ production cost of company $\mathrm{i}$ in period $\mathrm{t}$

$\mathrm{Ai}, \mathrm{t}-1=$ total assets of company $\mathrm{i}$ in period $\mathrm{t}$

Sit $=$ sales of company $\mathrm{i}$ in period $\mathrm{t}$

$\Delta \mathrm{Sit}=$ the difference in sales of company $\mathrm{i}$ in period $\mathrm{t}$

For all models, the value is absolute because this study only examines the amount of profit being manipulated but does not see the direction in which earnings management increases or decreases earnings.

\section{Audit Quality: Auditor Firm Size measure}

The size of the Auditor Firm Size where the auditor works is divided into Big Four and Non-Big Four Auditor Firm Size. Auditor Firm Size is measured on a nominal scale through dummy variables. The number 1 is used to represent the companies audited by the Big Four accounting firm and the number 0 for the others.

\section{Audit Quality: Auditor Independence}

Auditor independence is measured by the length of the working relationship between the client and the auditor or known as tenure. TENURE is the audit assignment period. This variable uses a dummy variable and is given a value of 1 if the length of the auditor's relationship with the client is 3 years or less, and a value of 0 if the others

\section{Institutional Ownership}

(Beiner et al., 2003) stated that institutional ownership is the percentage of voting rights held by the institution. In this study, institutional ownership is measured using the percentage indicator of the number of shares owned by the institution of all outstanding share capital.

INST $=\underline{\text { Number of shares owned by institutional investors }}$

The total outstanding share capital of the company 


\section{Management Ownership}

Manager ownership is the percentage of total share ownership by management of all share capital of the company being managed (Boediono, 2005). This variable is measured by the percentage of the number of shares owned by the management of all the company's capital owned.

KPMJ = The number of shares owned by the managementdevide by The total outstanding share capital of the company

\section{Foreign Ownership}

Foreign ownership is measured by the percentage of shares owned by foreign investors. Share ownership is measured by counting the total shares owned by all foreign ownership.

$\mathrm{KPA}=$ Number of shares owned by foreign partiesdevide by The total outstanding share capital of the company

\section{3.c. Data analysis method}

The data in this study were tested by multiple regression analysis with the following regression formula:

$\mathrm{RA}=\alpha+\beta 1$ AUDITOR FIRM SIZE $+\beta 2 \mathrm{INDPN}+\beta 3 \mathrm{INST}+\beta 4 \mathrm{KPMJ}+\beta 5 \mathrm{KPA}+\varepsilon$

Where :

$$
\begin{aligned}
& \alpha=\text { constant } \\
& \beta=\text { variable coefficient } \\
& \text { RA = Real Activity value } \\
& \text { KAP = Auditor Firm Size } \\
& \text { INDPN = Auditor Independence } \\
& \text { INST = Institutional Ownership } \\
& \text { KPMJ = Management Ownership } \\
& \text { KPA = foreign ownership } \\
& \text { e = residual of error }
\end{aligned}
$$

\section{Results And Discussion}

\subsection{Descriptive statistics}

The initial sample for observing earnings management through real activities is 306 company data, minus 113 outliers. The final sample contained 175 Firm Years. Table 1 presents descriptive statistics described according to the research model. 
Table 1. Descriptive Statistics

\begin{tabular}{|l|l|l|l|l|l|}
\hline & $\mathrm{N}$ & Minimum & Maximum & Mean & Std. Deviation \\
\hline INST & 175 &, 00000 &, 29180 &, 0168669 & 05251525 \\
KPMJ & 175 &, 00000 &, 17970 &, 0179222 & 04121258 \\
KPA & 175 &, 00000 &, 99000 &, 3828669 & 31823560 \\
LEV & 175 &, 0395489455 & 1,1070584471 & .439251149327 & 2175731919965 \\
GROWTH & 175 &,- 3634664961 & 6177405374 &, 111827643416 &, 1801197149355 \\
SIZE & 175 & 11,36143 & 16,37039 & 13,7510748 & 1,13642076 \\
& & 247,99738844 & 2086235,8094850 & 182783,0074101 & 310314,15159695650 \\
ACFO & 175 & 7760 & 27000 & 7557000 & 0000 \\
& & 5007,0064849 & 1786513,6553844 & 234819,7315197 & 324367,52018976980 \\
ADISEXP & 175 & 17204 & 55000 & 3510000 & \\
APROD & 175 & 32732,241255 & 15642421,669309 & 1588942,169185 & 2392317,3482029200 \\
& & 569160 & 491000 & 89830000 & 00000 \\
Valid & $N$ & & & & \\
(listwise) & 175 & & & & \\
\hline
\end{tabular}

$\begin{array}{ll}\text { Proportion } & \text { Proportion } \\ \text { Dummy }=1 & \text { Dummy }=0\end{array}$

\begin{tabular}{lll}
\hline KAP & $37 \%$ & $63 \%$ \\
INDP & $72 \%$ & $28 \%$ \\
N & &
\end{tabular}

ACFO = abnormal cash flow from operation, ADISEXP $=$ abnormal discretionary expense, APROD = abnormal discretionary production cost. INST = Agency Ownership, KMPJ = Management Ownership, KPA = Foreign Ownership, AUDITOR FIRM SIZE = 1 if the company is audited by AUDITOR FIRM SIZE Big 4 and 0 otherwise, INDPN = Auditor Independence, LEV = ratio of current liabilities to total assets, GROWTH $=$ SIZE Sales Growth Rate = natural logarithm of market value, SIZE = natural logarithm of market value.

Table 2 presents a summary of the test results with 3 models of real earnings management.

Table 2. Summary of Regression Results

\begin{tabular}{|l|l|l|l|l|l|l|}
\hline \multirow{2}{*}{ Component } & \multicolumn{6}{l}{ MetodeEarnings Management } \\
\cline { 2 - 7 } & ACFO & \multicolumn{2}{l|}{ ADISEXP } & & APROD & \\
\hline Anova (f) & 12,662 & $* * *$ & 24.716 & $* * *$ & 27.320 & $* * *$ \\
\hline Adjusted R & 0,349 & & 0.522 & & 0.548 & \\
\hline Constant & $-2114452,335$ & & -2616579.378 & $* * *$ & $-22047037,215$ & $* * *$ \\
\hline INST & $-101086,027$ & & $-675823,083$ & $* *$ & $-1009335,144$ & \\
\hline KPMJ & 537655,267 & & $-642724,821$ & & $-2313478,659$ & \\
\hline KPA & 24372,181 & & $-146748,359$ & $* *$ & 549344,067 & \\
\hline KAP & 19573,939 & & $-214327,003$ & $* * *$ & $-1548470,967$ & $* * *$ \\
\hline INDPN & 51750,928 & & 79870,791 & & 351506,778 & \\
\hline LEV & $-216300,936$ & $* *$ & $-523515,385$ & $* * *$ & $-1619251,721$ & $* *$ \\
\hline GROWTH & 19635,326 & & $-75693,754$ & & $-146029,629$ & \\
\hline SIZE & 169314,530 & $* * *$ & 232056,175 & $* * *$ & 1784136,204 & $* * *$ \\
\hline & & & & & & \\
\hline
\end{tabular}

**Significant at $1 \%$ level $\quad * * *$ Significant at $5 \%$ level

ACFO = abnormal cash flow from operation, ADISEXP = abnormal discretionary expense, APROD = abnormal discretionary production cost. INST = Agency Ownership, KMPJ = Management Ownership, KPA = Foreign Ownership, AUDITOR FIRM SIZE $=1$ if the company is audited by AUDITOR FIRM SIZE Big 4 and 0 
otherwise, INDPN = Auditor Independence, $\mathrm{LEV}=$ ratio of current liabilities to total assets, GROWTH $=$ SIZE Sales Growth Rate $=$ natural logarithm of market value, SIZE $=$ natural logarithm of market value.

Institutional ownership (INST) is not proven to have an effect on real activity earnings management through the abnormal cash flow from operation model and through the abnormal production cost model. In these two models, institutional ownership cannot reduce earnings management through real activities of managers. The results of this study do not support Veronica and Utama's (2006) research which states that the proportion of institutional ownership has a positive but insignificant effect on earnings management. This result is also contrary to Nuraini and Zain (2007) who concluded that institutional ownership has a negative effect on earnings management. However, the results of this study are in line with the research of Ujiyantho and Pramuka (2007) which also obtained the same results. The absence of a significant influence between institutional ownership and earnings management through CFO and APROD is probably also due to the small number of institutional ownership in this study. The descriptive statistics table shows that the average institutional ownership is only $1.6 \%$. In addition, there is a possibility that the cause is not significant because earnings management through real activities in this method is seen based on the company's operating cash flow statement, which results in earnings management being difficult to detect by owners, even banks and financial institutions.

Unlike the two previous models, the abnormal discretionary expense model shows that institutional ownership has a negative effect on earnings management. The coefficient of institutional ownership in the abnormal discretionary expense model is because the $\mathrm{p}$ value is 0.046 below the alpha significance level of $5 \%$. This means that institutional ownership can reduce earnings management through abnormal discretionary expense. The results of this model support the research of Veronica and Utama (2006) and Nuraini and Zain (2007) which state that the proportion of institutional ownership has a negative and significant effect on earnings management. However, the results of this study do not support the research of Ujiyantho and Pramuka (2007) which also obtained different results, namely that institutional ownership has no effect on the abnormal discretionary expense variable. The finding of a significant negative effect between institutional ownership and earnings management in this study means that institutional ownership is able to reduce earnings management through real activities with the discretionary expense method.

The managerial ownership variable in all models is not significant. Managerial ownership in this study cannot maximally monitor the occurrence of earnings management in the company which is carried out through real activities. Thus the hypothesis of this study which states that managerial ownership has a negative effect on earnings management through real activities is rejected. The results of this study do not support the research of Iqbal (2007) and Ujiyantho and Pramuka (2007) which state that managerial ownership has a negative and significant effect on earnings management. However, the results of this study are consistent with the research of Welvin and Herawaty (2010) which states that managerial ownership has no effect on earnings management. The possible reason for the insignificant relationship is that managerial ownership in Indonesia is still very small, only $1.7 \%$. With this relatively small ownership, the ability of this ownership to monitor management is also small. In addition, it is possible because most of the characteristics of public companies in Indonesia are concentrated in the family so that managers are part of the owner but not recorded. Concern for the transparency of financial reports is not so important because of the concentration of ownership in the family. This researcher's initial statement is based on the results of observations and interviews with several middle managers in several public companies. Still needs to be proven in further research.

Meanwhile, foreign ownership, which amounts to an average of about $40 \%$, is only significant in the abnormal expenditure expense model. In the abnormal CFO model and the abnormal Production cost variable, this has no significant impact on earnings management. The hypothesis which states that foreign ownership has a negative effect on earnings management through real activities is only accepted in the abnormal expenditure expense model. Foreign ownership in this model is proven to be able to monitor maximally the occurrence of earnings management in the company.

The effect of foreign ownership on real earnings management is not clearly captured in the two models. The descriptive statistical table also shows that the average foreign ownership in the sample companies is $38 \%$ of the total ownership. This amount should be sufficient to contribute to company supervision. The possible causes for the impact are not significant, due to the weakness of the method of measuring this variable. This study looked at foreign ownership based on the owner's name which contained the words Ltd (Limited), Intl (International), and Pte. It is probable that the sample companies in the manufacturing industry in Indonesia whose names contain these words are not purely owned by foreign investors. Only foreign terms are used but are actually owned by domestic investors.

The impact of audit quality as measured by Auditor Firm Size is not significant in the abnormal CFO model. However, in the abnormal model of production costs and abnormal expenditure, it is evident that the size of Auditor Firm is able to reduce the occurrence of earnings management through real activities. This study also differs from the findings of Chi et al. (2011) who found evidence of a positive relationship between audit quality 
and forms of real transaction earnings management, including abnormal cash flows, abnormal production costs, abnormal operating costs from the Roychowdhury (2006) model.

The test results on the existence of independent auditors are not proven to be able to suppress earnings management through real activities in all models. Thus the hypothesis of this study which states that audit quality as measured by auditor independence has a negative effect on earnings management through real activities is rejected. This study is inconsistent with the results of Meutia's (2004) study which states that auditor independence can be a factor in detecting earnings management. However, this study supports the results of research by Welvin and Herawaty (2010) which concluded that auditor independence has no effect on earnings management. In this study, it can be seen from the average value on descriptive statistics that $68 \%$ of the research sample companies have used different Auditor Firm Size services after three years. However, the effect of auditor independence on earnings management is not visible. Possible cause is that auditors have not been able to detect the occurrence of earnings management through the company's financial statement audit process. In line with the statement of Chi et al., (2011).

The control variable that has a significant effect on earnings management through all measures of real activity is SIZE of the firm. The bigger the size of the company, the more motivated it will be to do earnings management through real activities. Meanwhile, companies with high debt levels actually lack incentives to carry out earnings management through real activities. The variable rate of sales growth has no impact on earnings management through real activities.

The constant value in the ACFO model is $-2114452.335 \mathrm{p}$, there is an ADIEXP model of -2616579.378 and the APROD model is -22047037.215 . All constant values are negative and significant at the $1 \%$ level. This means that earnings management through real activities occurs significantly by reducing the abnormal value of $\mathrm{CFO}$, abnormal discretionary expenditure and manipulating abnormal production costs. In this study, the sample companies did not try to increase their profits but instead decreased their earnings reporting. This finding is interesting because it turns out that managers are not motivated to increase profits to improve their performance. The decline in profit is probably related to the ownership structure, which results in the majority of which are not optimal in supervising company management. The suspicion is that the agency problem in Indonesia is different from abroad. The ownership structure that is concentrated on the controlling owner makes the agency problem in Indonesia more specific than in other countries. Agency problems do not occur between managers and owners because most ownership in Indonesia is concentrated on the controlling owner. Wealth transfers that occur are not between manager-owner but between companies and stakeholders other than owners, for example the government. The decline in profits in this study may be aimed at avoiding taxes. The owner is more concerned with keeping his money out of his pocket than on the integrity of his financial statements. This assumption is supported by the level of debt which has a significant impact on the decline in earnings management. When companies have a lot of debt, they are reluctant to do earnings management because they already have compensation for their tax payments.

Of the three methods of earnings management through real activity, the easiest to detect with ownership structure and quality of equity are the abnormal discretionary expense and abnormal production cost methods. This is probably because in calculating the abnormal discretionary exposure and abnormal production cost methods, all the company cost instruments are included. The sample companies perform earnings management in real activities by increasing production costs for the purpose of reducing company profits.

\section{Conclusion}

The test results on the abnormal CFO model show that auditor quality and ownership structure have no effect on earnings management. This result is probably due to the fact that earnings management carried out through real activities using abnormal cash flow is more difficult and more difficult to detect with the quality of auditors and by the ownership structure. The growth control variable used in this model is not proven to have an effect on earnings management through real activities. Meanwhile, another control variable, namely firm size, is proven to have a positive effect on earnings management through real activities. The leverage control variable is proven to have a negative effect on real activity earnings management in this study.

Meanwhile, earnings management carried out through abnormal production costs is not proven to be influenced by ownership structure but is proven to be negatively affected by audit quality as measured by Auditor Firm Size. Companies audited by big 4 accounting firms are proven to have less real activity management than companies audited by non-big accounting firms 4 . Control size and leverage variables are proven to have positive and negative effects on earnings management through real activities for abnormal production cost models.

In the abnormal discretionary expense method, earnings management through real activities is proven to be influenced by ownership structure and audit quality. Only managerial ownership is not proven to affect earnings management through real activities. The results also show that institutional ownership and foreign ownership can 
play a good monitoring function so that earnings management through real activities decreases in line with the increase in institutional and foreign ownership of shares. Audit quality as measured by the independence and size of Auditor Firm Size is also proven to be able to reduce real earnings management on activities. The control variable in this study, namely company size has a positive impact on earnings management and leverage is proven to have a negative effect. Meanwhile, growth has no effect on real activity earnings management practices through the abnormal production cost model.

\section{Result implications}

This study proves that earnings management through real activities can be detected through improving audit quality and the role of institutional ownership. Audit quality needs to be maintained in order to be able to detect earnings management. Investors need to see who owns the company before deciding to invest.

\section{Research Limitations}

This study uses foreign ownership and managerial ownership whose results are not significant. The possible cause is because of the small percentage of share ownership by company managers because not many companies give their shares to their management. In addition, there may be a measurement error on foreign ownership variables that only use names, even though there may be foreign names but ours. Therefore, further research can overcome by improving the size of foreign ownership by tracing to the ultimate control of the company (end owner).

\section{Suggestions}

The independent variables and control variables used in this study only explain $3 \%$ of the variation in the dependent variable, the rest there are many other variables that are not included in this research model. Because the relationship between the dependent variable that can be explained by the independent and control variables in the study is still very small, it means that there are still many opportunities for further researchers to examine other independent variables that have an influence on earnings management, such as good corporate governance, intellectual capital disclosure, corporate. social responsibility, and so on.

Measurement of the dependent variable earnings management only uses real activities and does not take into account factors other than accounts receivable, income, company size, company age, growth revenue and gross margin. Future research can use two measures of earnings management. For example, in addition to using real activities, accruals also include adding other earnings management measures that take into account factors that cannot be controlled by managers such as economic conditions, interest rates, and inflation. Thus it can be seen that the existence of earnings management from two different points of view is then compared together so that the results are more accurate..

\section{References}

Alves, Sandra. 2012. Ownership Structure and Earning Management: Evidence From Portugal. Australian Accounting Business and Finance Journal, Vol. 6

Muhammad Bilal Saeed, Syed Kashif Saeed. 2018. Corporate Governance and Accounting Conservatism: Moderating role of Audit Quality and Disclosure Quality. Business \& Economic Review: Vol. 10, No.2 2018 pp. 123-150 DOI: dx.doi.org/10.22547/BER/10.2.6

Bartov, Eli \& Gul, Ferdinand \&Tsui, Judy. (2000). Discretionary-Accruals Models and Audit Qualifications. SSRN Electronic Journal. 10.2139/ssrn.214996.

Beiner, S., Drobetz, W., et al, 2003, Is Board size an Independent Corporate Governance Mechanism, www.ssrn.com

Boediono, Gideon. 2005. KualitasLaba: StudiPengaruhMekanisme Corporate Governance dan DampakManajemenLabadenganMenggunakanAnalisis Jalur. Simposium Nasional Akuntansi (SNA) VIII Solo.

Caskey, Judson \& Laux, Volker. (2016). Corporate Governance, Accounting Conservatism, and Manipulation. Management Science. 63. 10.1287/mnsc.2015.2341.

Cohen. Daniel A. and Zarowin. Paul. 2010. Accrual-based and real earnings management activities around seasoned equity offerings. Journal of Accounting and Economics. vol. 50, issue 1, 2-19

Darmawati, D. (2005), Corporate Governance dan ManajemenLaba: SuatuStudiEmpiris, JurnalBisnis dan Akuntansi, Vol. 5, No. 1, April, Hal. 47-68.

Eisenhardt, Kathleen. M. Agency Theory: An Assesment and Review. Academy of Management Review, 14, $57-$ 74, 1989.

Eldenburg, Leslie \&Soderstrom, Naomi \& Gunny, Katherine \&Hee, Kevin. (2011). Earnings Management Using Real Activities: Evidence from Nonprofit Hospitals. The Accounting Review. 86. 10.2308/accr-10095.

Fama, Eugene F and Jensen, M.C. 1983. Agency Problems and Residual Claims. Journal of Law \& Economics, Vol. XXVI. Avalaible from: http://papers.ssrn.com 
Healy, Paul M. and J.M. Wahlen. (1999). A Review Of The Earnings Management Literature And Its Implications For Standard Setting. Accounting Horizons 13, 365-383.

Herusetya, Antonius. 2014.Pengaruh ukuran auditor dan spesialisasi auditor terhadapkualitaslaba. JurnalAkuntansi dan Keuangan Indonesia. Volume. 6. Issue 1. Pages.46-70

Jensen, M. and Meckling, W., 1976, "Theory of the Firm: Managerial Behavior Agency Cost, and Ownership Structure", Journal of Finance Economics 3,pp. 305-360.

Komite Nasional Kebijakan Governance. 2006. PedomanUmum Governance Indonesia.

Lev, Baruch. 1989. Current Studies on The Information Content of Accounting Earnings Journal of Accounting Research.Vol. 27, pp. 153-192

Nur'aini, Mufida. StudiPerbandingan Model Revenue dan Model Accrual DalamMendeteksiManajemenLaba (Studi pada Perusahaan Manufaktur yang Terdaftar di Bursa Efek Indonesia Tahun 2006-2010). Semarang: Universitas Diponegoro, 2012.

Ramaswamy, K., \&Mingfang, L. (2001). Foreign investors, foreign directors and corporate diversification: An empirical examination of large manufacturing companies in India. Asia Pacific Journal of Management, 18(2), 207-22. https://doi.org/10.1023/A:1010620008101

Ratmono,Dwi.(2010).”ManajemenLabaRiil dan BerbasisAkrual:Dapatkah. Auditor yang BerkualitasMendeteksinya?’.Simposium Nasional Akuntansi XIII.

Ronen, Joshua \&Yaari, Varda. (2008). Earnings Management: Emerging Insights in Theory, Practice, and Research. 10.1007/978-0-387-25771-6.

Scott, W.R. 2015. "Financial Accounting Theory". Seventh Edition. Ontario: Prentice Hall Canada Inc.

Siregar, Sylvia Veronica dan Siddharta Utama. 2005. PengaruhStrukturKepemilikan, Ukuran Perusahaan, dan Praktik Corporate Governance terhadapPengelolaanLaba (Earnings Management). Simposium Nasional Akuntansi VIII, Solo, 2005.

Sulistyanto, Sri. ManajemenLaba: Teori dan Model Empiris. Jakarta: PenerbitGrasindo, 2008.

Roychowdhury, S. 2006. "Earnings Management through Strukturkepemilikan Manipulation." Journal of Accounting and Economics. 42: 335-370.

Teoh, S.H., Welch, I., Wong, T.J., 1998a. Earnings management and the long-run market performance of initial public offerings. Journal of Finance 53, 1935-1974.

Ujiyantho dan Pramuka, 2007. Mekanisme Corporate Governance, ManajemenLaba dan Kinerja Keuangan (Studi Pada Perusahaan go publikSektorManufaktur), JurnalSimposium Nasional Akuntansi X. Makasar

Sylvia dan Yanivi S Bachtiar. 2004. Good Corporate Governance Information Asymetry and Earnings Management. Artikel yang Dipresentasikan pada Simposium Nasional Akuntansi 7 Denpasar tanggal $2-3$ Desember 2004

Salvatore. 2005. Managerial Economics, Pasar Modal \&ManajemenPortofolio 5 th edition. PenerbitSalembaEmpat.

Watts, R, L., and Zimmerman, J, L. 1986, Positive Accounting Theory. New York, Prentice Hall.

Wuchun Chi, Ling Lei Lisic, Mikhail Pevzner (2011) Is Enhanced Audit Quality Associated with Greater Real Earnings Management?. Accounting Horizons: June 2011, Vol. 25, No. 2, pp. 315-335. https://doi.org/10.2308/acch-10025

Utami, Wiwik. 2006. Pengaruhmanajemenlabaterhadapbiaya modal ekuitas (Studi pada perusahaanpubliksektormanufaktur). The Indonesian Journal of Accounting Research. http://doi.org/10.33312/ijar.155

ZanginaIsshaq; Godfred A. Bokpin and Joseph Mensah Onumah, (2009), Corporate governance, ownership structure, cash holdings, and firm value on the Ghana Stock Exchange, Journal of Risk Finance, 10, (5), 488499C. 